\title{
R-plasmid RP 1 promotes adhesion of gram-negative bacteria to medical prostheses and glass
}

\author{
J. A. ONAOLAPO*, M. I. A. EL-HAFFAR, D. TOWNLEY and R. M. M. KLEMPERER $\dagger$
}

Microbiology Research Group, Department of Pharmaceutical Sciences, Aston University, Birmingham B4 7ET

\begin{abstract}
Summary. The presence of R-plasmid RP1 increased the adhesion of chemostatgrown iron- and carbon-limited Proteus mirabilis to the surfaces of various medical prostheses and to glass. Similar results were obtained with iron-limited Pseudomonas aeruginosa and anaerobically-grown Escherichia coli. Changes in the surface properties of $P$. mirabilis indicated that the R-plasmid-mediated increase in negative charge was one of the factors that promoted adhesion.
\end{abstract}

\section{Introduction}

Adhesion of bacteria to surfaces may be an important initial event in the pathogenesis of infectious diseases (Vosbeck and Mett, 1983) and adherent bacteria may be less sensitive to natural host defences (Costerton and Marrie, 1983) and to antibiotics (Gwynn et al., 1981) than are bacteria suspended in body fluids. Bacteria that adhere to prostheses may serve as foci of infection (Christensen et al., 1983) and antibiotic-resistant organisms are a particular problem (Eykyn, 1984).

R-plasmid RP1 mediates changes in the outer membrane of Pseudomonas aeruginosa (Kenward et al., 1978) and in the physicochemical surface properties of Escherichia coli (Klemperer et al., 1980) and Proteus mirabilis (Onaolapo and Klemperer, 1986). Its effects on adhesion to various inert surfaces have, therefore, been investigated with cells grown in continuous culture at approximate doubling times of $2 \mathrm{~h}$ and $7 \mathrm{~h}$, which lie well within the range of doubling times reported for bacteria growing in body fluids (Maw and Meynell, 1968; Hooke et al., 1985).

Because cell-envelope properties vary with the environment (Brown and Williams, 1985), the adhesion of several phenotypes was investigated in this study. Iron-limitation may be important in vivo because it is an important defence against infection (Griffiths, 1983). Phenotypic changes may be particularly marked in the presence of plasmids, because these place a major synthetic burden on

Received 9 Oct. 1986; accepted 23 Dec. 1986.

* Present address: Department of Pharmaceutics, Faculty of Pharmaceutical Sciences, Ahmadu Bello University, Zaria, Nigeria.

$\dagger$ Requests for offprints should be sent to Dr R. M. M. Klemperer. cells (Levin, 1980), particularly when they are energy-limited and grown in anaerobic conditions (Tempest, 1978). In this study iron- and carbonlimited cells have been investigated in aerobic conditions, and carbon-, phosphate-and potassiumlimited cells in anaerobic conditions.

\section{Materials and methods}

\section{Bacterial cultures}

Proteus mirabilis PB13, a motile, but non-swarming strain isolated from a urinary-tract infection, was supplied by $\operatorname{Dr}$ B. W. Senior, Ninewells Hospital, Dundee. Pseudomonas aeruginosa PAO1 (ATCC 15692) and Escherichia coli K12 W3110 (originally from Dr P. A. Meacock, Leicester University) were also used. Rplasmid RP1 from Professor E. J. L. Lowbury, The Accident Hospital, Birmingham, was transferred to these strains (Meynell and Meynell, 1970).

Stock cultures were maintained on Nutrient Agar (NA) (Oxoid) and the presence of the plasmid checked by plating on NA containing ampicillin $25 \mu \mathrm{g} / \mathrm{ml}$ for $P$. mirabilis, carbenicillin $200 \mu \mathrm{g} / \mathrm{ml}$ for Ps. aeruginosa and kanamycin sulphate $15 \mu \mathrm{g} / \mathrm{ml}$ for $E$. coli. The plasmid was stable under all conditions tested. Cells, with $\left(\mathbf{R}^{+}\right)$ and without $\left(R^{-}\right) R P 1$, were grown at $37^{\circ} \mathrm{C}$ in $50-\mathrm{ml}$ chemostats (Gilbert and Stuart, 1977).

\section{Media}

Simple salts media that provided at least a ten-fold excess of ingredients, unless otherwise stated, were prepared from Analar grade chemicals in double-distilled water.

For $P$. mirabilis, the medium contained $40 \mathrm{~mm}$ glucose, $0.2 \mathrm{mM}\left(\mathrm{NH}_{4}\right)_{2} \mathrm{SO}_{4}, 0.2 \mathrm{mM} \mathrm{MgSO}_{4}, 0.005 \mathrm{mM} \mathrm{FeSO}$, $30 \mathrm{mM} \mathrm{KCl}, 0.1 \mathrm{mM} \mathrm{NaCl}, 0.06 \mathrm{mM}$ nicotinic acid and

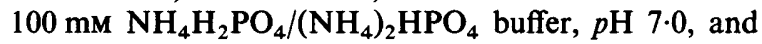
had an osmolarity equivalent to $0.85 \%$ saline. For glucose- 
limited cultures, glucose was reduced to $3 \mathrm{~mm}$, and for iron-limited cultures, iron was omitted and the phosphate buffer passed once, before use, through a column of Chelex 100 ion exchange resin (Bio-Rad Laboratories, Watford).

For Ps. aeruginosa, iron was not added and the medium contained $40 \mathrm{mM}$ glucose, $40 \mathrm{mM}\left(\mathrm{NH}_{4}\right)_{2} \mathrm{SO}_{4}, 0.4 \mathrm{mM}$ $\mathrm{MgSO}_{4}, 0.62 \mathrm{~mm} \mathrm{KCl}, 5 \mathrm{mM} \mathrm{NaCl}, 3.2 \mathrm{mM} \mathrm{K}_{2} \mathrm{HPO}_{4}$, $60 \mathrm{~mm}$ 3-N-morpholinopropane sulphonic acid (MOPS) buffer, $p \mathbf{H} 7 \cdot 8$.

For $E$. coli, the medium contained $20 \mathrm{~mm}$ glucose, $22.2 \mathrm{mM} \mathrm{NH} \mathrm{NH}_{4}, 0.2 \mathrm{mM} \mathrm{MgSO}_{4}, 0.002 \mathrm{MM} \mathrm{FeSO}_{4}$, $5.6 \mathrm{mM} \mathrm{KH}_{2} \mathrm{PO}_{4}, 1.8 \mathrm{mM} \mathrm{Na}_{2} \mathrm{HPO}_{4}$ and MOPS buffer $50 \mathrm{mM}, p \mathrm{H} \mathrm{7 \cdot 6}$. For glucose-limited cultures, glucose was reduced to $3 \mathrm{mM}$, for phosphate-limited cultures $\mathrm{KH}_{2} \mathrm{PO}_{4}$ was reduced to $0.1 \mathrm{mM}$ and $\mathrm{Na}_{2} \mathrm{HPO}_{4}$ replaced by $1.8 \mathrm{mM}$ $\mathrm{NaCl}$ and for potassium-limited cultures $\mathrm{KH}_{2} \mathrm{PO}_{4}$ was reduced to $0.03 \mathrm{mM}$.

$P$. mirabilis and $P$ s. aeruginosa cultures were aerated by passing $\mathrm{O}_{2}$ through a sinter at the base of the chemostat at $35 \mathrm{ml} / \mathrm{min} ; E$. coli was grown anaerobically by passing $\mathrm{O}_{2}$-free $\mathrm{N}_{2}$ through the medium at $40 \mathrm{ml} / \mathrm{min}$.

\section{Measurement of adhesion}

Cultures of $\mathbf{R}^{+}$and $\mathbf{R}^{-}$cells were established in chemostats and then mixed by the transfer of $1-10 \%$ of each culture to the other. At the same time pieces of sterile prostheses or glass slides were added to the chemostat chambers as required. Cultures were harvested after about 50 generations. Surfaces of prostheses or slides were rinsed twice with $10-\mathrm{ml}$ volumes of saline to remove loosely attached cells and were then swabbed vigorously. Swabs, and the objects studied, were shaken vigorously in $5 \mathrm{ml}$ of saline in a vortex mixer. The walls of the chemostat were washed twice with 50-ml volumes of saline, swabbed vigorously and the swabs shaken vigorously as before. To determine the proportion of $\mathrm{R}^{+}$ cells in a mixture, samples were counted on NA and NA plus antibiotic. The results were compared with counts of bacteria suspended in the medium. Single-culture chemostats were treated similarly.

\section{Measurement of surface charge}

Electrostatic interaction chromatography as described by Pedersen (1981) was used to measure the relative surface charge. Cells were harvested, washed twice and resuspended in various concentrations of $\mathrm{NaCl}$ in $0.01 \mathrm{M}$ phosphate buffer to $E_{470} 5 \cdot 0$. A $0 \cdot 1-\mathrm{ml}$ volume of each suspension was applied to the top of a column prepared in a Pasteur pipette, from QAE sephadex (anion exchanger; functional group quaternary ammonium) or CM sephadex (cation exchanger; functional group sulphonic acid) (Pharmacia Fine Chemicals, AB Uppsala, Sweden; beadsize $40-120 \mu \mathrm{m}$ ). Elution was performed at once, with $2 \mathrm{ml}$ of suspending medium; the eluate was collected and the $E_{470}$ measured. Results are expressed as percentage absorbance, i.e., $E_{470}$ eluate as a percentage of $E_{470}$ initial suspension.

\section{Results}

\section{Adhesion of mixed cultures to surfaces}

The proportion of $\boldsymbol{P}$. mirabilis $\mathrm{R}^{+}$cells adherent to various medical prostheses and to glass was always 10 to 100 times greater than that in the surrounding liquid culture (fig. 1). Sampling accuracy was high, but there was considerable fluctuation in results when samples were taken on different occasions. It was, therefore, not possible to establish with certainty whether there were significant variations in adherence by cells grown in different conditions, although, generally, iron-limited $\mathbf{R}^{+}$ cells adhered in greater numbers than did carbonlimited ones. Growth rate, in contrast, seemed to have little effect.

Similar results were obtained with iron-limited Ps. aeruginosa. After 75 doublings $\left(\mathrm{D}=0 \cdot 1 \mathrm{~h}^{-1}\right)$, the percentage of $\mathrm{R}^{+}$cells in the medium had fallen to $0.1 \%$ but the percentage attached to dacron used for arterial grafts and to pieces of urinary catheter (silicone rubber) was in the range 60-75\%. E. coli was not tested with medical prostheses. However, anaerobically-grown carbon-, phosphate- and potassium-limited cells all showed a similar differential adhesion to glass, the $R^{+}: R^{-}$ratio being eight to eighty times higher than in the liquid, a ratio similar to that found for adhesion to glass by $P$. mirabilis.

\section{Adhesion of pure cultures of $P$. mirabilis to surfaces}

Comparison of pure cultures which had the same count of suspended cells (fig. 2) indicated differences in adherence between $\mathrm{R}^{+}$and $\mathrm{R}^{-}$cells, although the differences were not as great as in mixed cultures.

\section{Effect of R-plasmid RP1 on the surface charge of $P$. mirabilis}

More $P$. mirabilis $\mathrm{R}^{+}$cells than $\mathrm{R}^{+}$cells adsorbed to $\mathrm{QAE}$ sephadex indicating that the former are relatively more negatively charged than the latter in these conditions (fig. 3). There was no difference in the adsorption of $\mathrm{R}^{+}$and $\mathrm{R}^{-}$cells to $\mathrm{CM}$ sephadex.

\section{Discussion}

The increase in adhesion associated with plasmid RP1 is in contrast to the action of the multiresistant plasmid described by Denoya et al. (1986), which decreased adherence of Klebsiella pneumoniae to a 


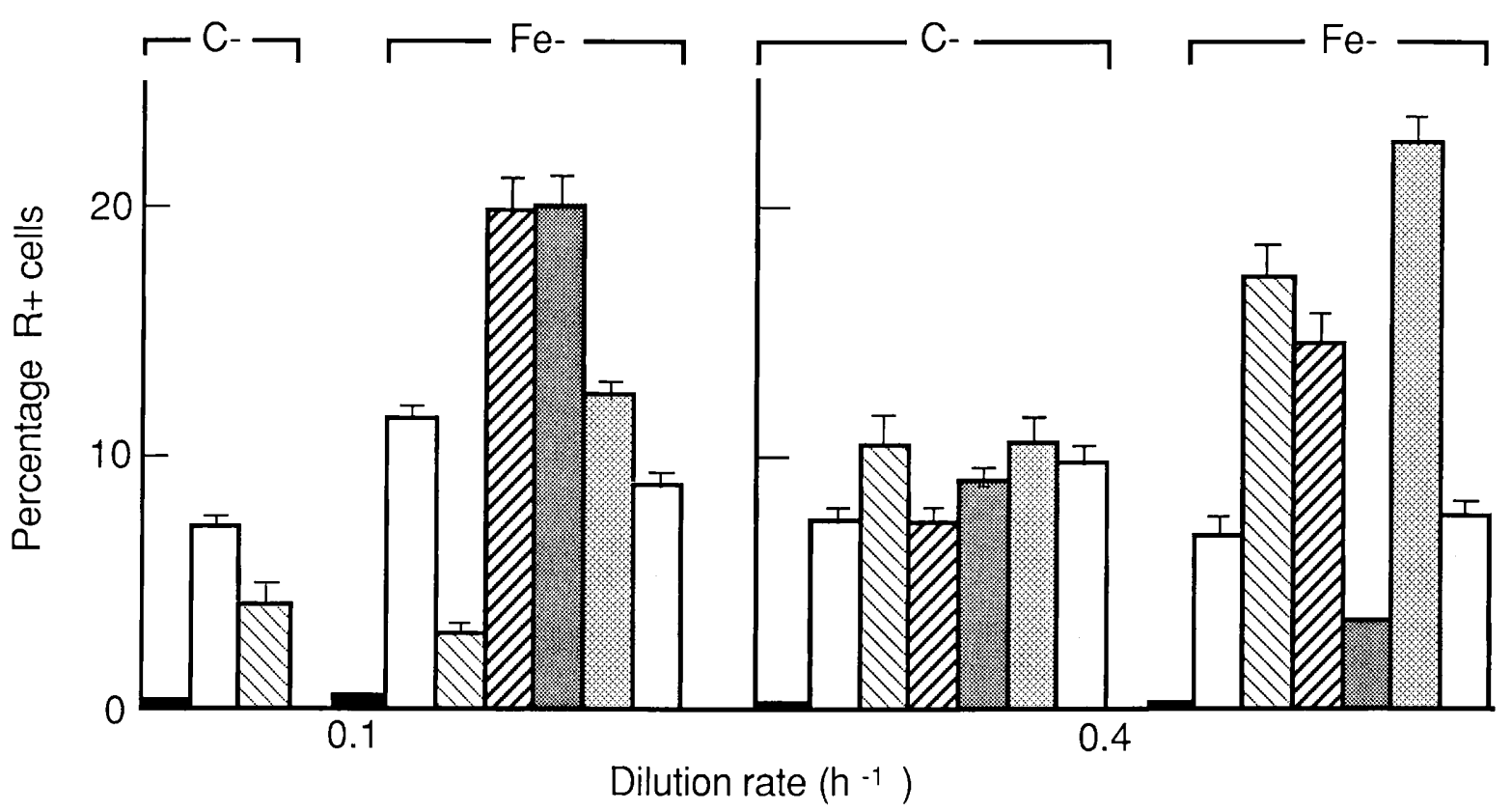

Fig. 1. Adhesion of mixed cultures of $\mathbf{R}^{+}$and $\mathbf{R}^{-} P$. mirabilis, carbon-limited (C-) and iron limited (Fe-) cells, after 50 doublings; percentage of $R^{+}$cells in the culture medium ( $\square$ ), on glass $(\square)$, on a urinary catheter (silicon) (Dow Corning Medical, Valbonne, France) $(\mathbb{Q})$, on an intravenous cannula $\left(\operatorname{Venflon}^{\mathrm{R}}\right)(\mathbb{Z})$, on an intravenous catheter placement unit $\left(\right.$ Angiocath $\left.{ }^{R}\right)($ 㘣), on an endotracheal tube (Porex Ltd, Hythe, Kent) (晜) and on dacron (Vascutek knitted) (Coats Pacesetter Ltd, East Kilbride) ( $\square$ ). Bars indicate $\mathrm{SD}$, except where they were too small to be recorded.

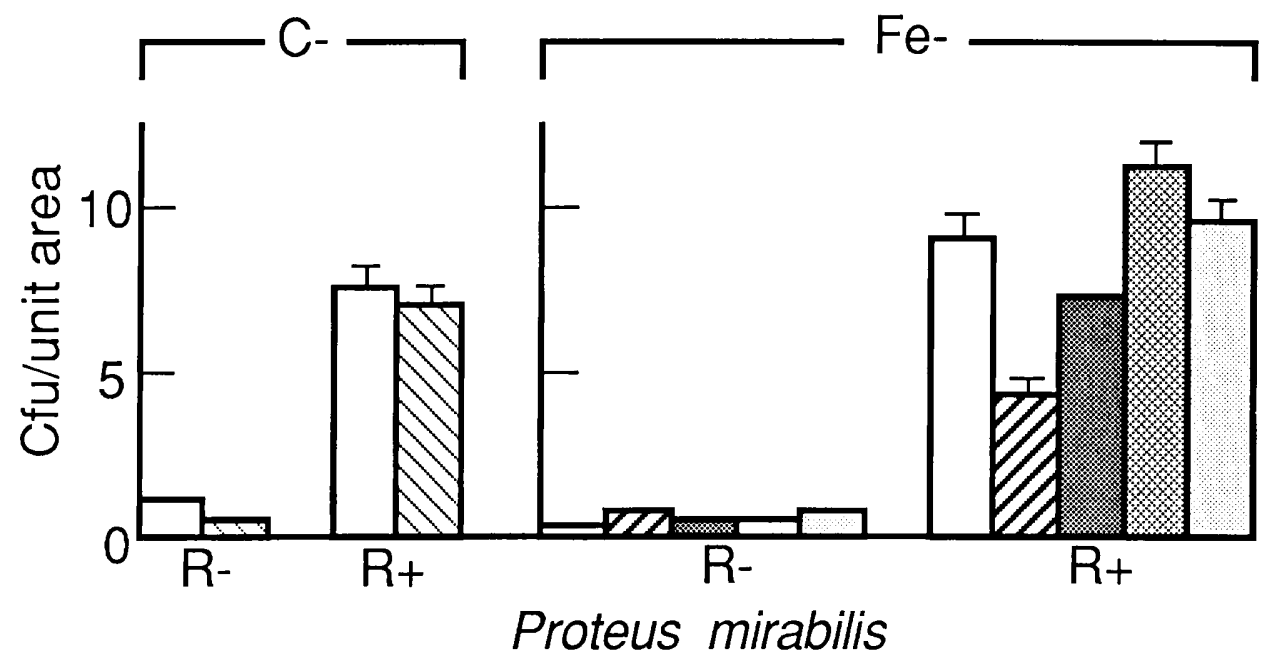

Fig. 2. Adhesion of pure cultures of $P$. mirabilis $\mathbf{R}^{+}$and $\mathbf{R}^{-}$, carbon-limited (C-) and iron-limited (Fe-) after 50 doublings at $\mathrm{D}=0.1 \mathrm{~h}^{-1}$; Symbols used are the same as in fig. 1. Bars indicate SD, except where they were too small to be recorded.

cerebrospinal fluid shunt. Plasmid RP1 is an Inc $\mathbf{P}$ plasmid and the relatively high percentage of $\mathbf{R}^{+}$ cells in surface growth from mixed cultures is probably partly due to surface transfer (Bradley $e t$ al., 1980). However, plasmid RP1 also promotes the adherence of cells in pure culture, which suggests a direct effect on surface properties.

Differences in adhesion between $\mathrm{R}^{+}$and $\mathrm{R}^{-}$ cells were most easily demonstrated after growth in iron-limited conditions, although results of samples 


\section{Dilution rate $\left(\mathrm{h}^{-1}\right)$}

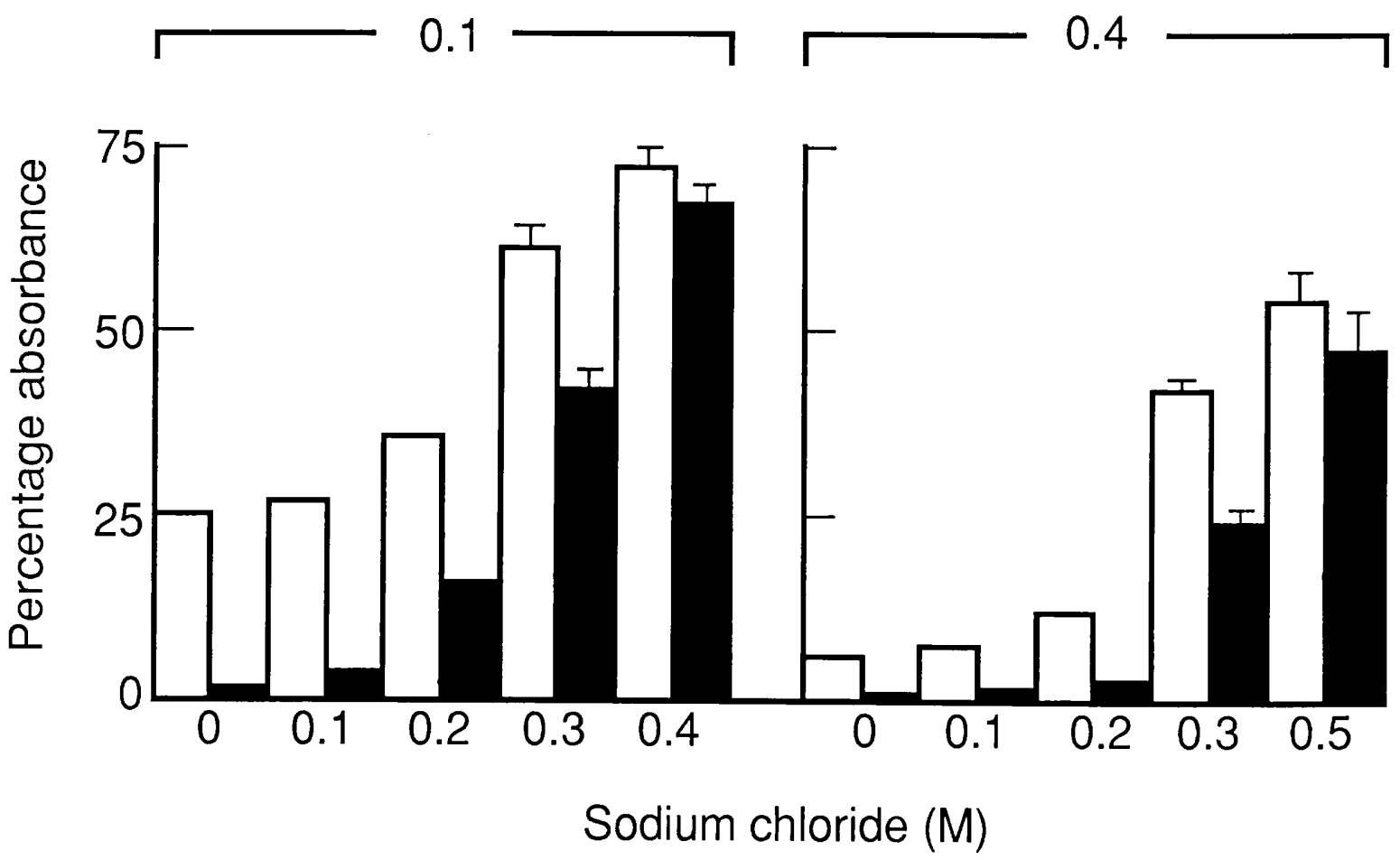

Fig. 3. Surface charge of iron-limited $\mathrm{R}^{-}(\square)$ and $\mathrm{R}^{+}(\square)$ P. mirabilis, measured by adherence to QAE sephadex (anion exchanger). Bars indicate SD except where they were too small to be recorded.

taken on different occasions varied, possibly because accumulations of adherent bacteria were dislodged into the liquid from time to time as a result of continuous mixing (Costerton and Marrie, 1983). Adhesion to inert surfaces has been used as a model for adherence to tissues (Harber et al., 1983) and the effect of the plasmid on anaerobicallygrown cells suggests that adhesion may be important in the maintenance of $\mathbf{R}^{+}$cells in the gut.

The accumulation of bacteria on a surface is the net result of several factors (Berkeley et al., 1980) of which hydrophobic interactions have often been considered to be of prime importance (Dahlbäck $e t$ al., 1981). However, although plasmid RP1 codes constitutively for sex pili (Bradley, 1983), which might be expected to increase host cell hydrophobicity (Tewari et al., 1985), $\mathrm{R}^{+}$cells of $\boldsymbol{P}$. mirabilis are less hydrophobic than $\mathbf{R}^{-}$cells when grown in continuous culture in the same conditions as those reported here (Onaolapo and Klemperer, 1986). Hydrophobic interactions do not therefore, appear to account for the initial stages of adhesion. Cells in the fluid in a continuous culture system are growing exponentially. Once they have adhered to a surface and become embedded in a microcolony, conditions will be different and some cells may effectively be stationary. Stationary-phase $\mathbf{R}^{+}$cells of $P$. mirabilis are more hydrophobic than $\mathrm{R}^{-}$cells, particularly when they are iron-limited.

Solid surfaces are normally negatively-charged when immersed in water (Marshall, 1980) and increased adherence of Neisseria meningitidis and Mycoplasma pneumoniae was found under conditions in which the net negative charge was reduced (Feldner et al., 1983; Criado et al., 1985). The increase in negative charge of $\mathrm{R}^{+}$cells, both of $E$. coli (Klemperer et al., 1980) and of P. mirabilis, whether chemostat-grown or in stationary phase (Onaolopo, 1986), at first appears anomalous. However, adhesion was measured during growth, in a medium which included an excess of magnesium ions and it has been suggested that an increase in negative charge might provide increased binding sites for divalent cations, which act as a bridge between the bacterial cell and a surface. Such a mechanism might explain the adherence of oral streptococci and Shigella spp. to surfaces (Nesbitt et al., 1982; Kabir et al., 1985). Similarly, plasmid- 
mediated, charge-dependent adherence of Yersinia enterocolitica to hydroxyapatite was enhanced by the addition of calcium ions (Lachica and Zink, 1984). It is well known that surface growth is particularly important in nutrient-poor environments and the chemiosmotic theory has been used to explain why it is energetically advantageous for organisms to be attached to a surface (Ellwood et al., 1982). It would, therefore, seem to be particu-

\section{REFERENCES}

Berkeley R C W, Lynch J M, Melling J, Rutter P R, Vincent B (eds) 1980 Microbial adhesion to surfaces. Ellis Horwood, Chichester.

Bradley D E 1983 Specification of the conjugative pili and surface mating systems of Pseudomonas plasmids. Journal of General Microbiology 129: 2545-2556.

Bradley D E, Taylor D E, Cohen D R 1980 Specification of surface mating systems among conjugative drug resistance plasmids in Escherichia coli K-12. Journal of Bacteriology 143: 1466-1470.

Brown M R W, Williams P 1985 Influence of substrate limitation and growth phase on sensitivity to antimicrobial agents. Journal of Antimicrobial Chemotherapy 15: Suppl A 7-14.

Christensen G D, Simpson W A, Bisno A L, Beachey E H 1983 Experimental foreign body infections in mice challenged with slime-producing Staphylococcus epidermidis. Infection and Immunity 40: 407-410.

Costerton J W, Marrie T J 1983 The role of the bacterial glycocalyx in resistance to antimicrobial agents. In: Easmon C S F et al. (eds) Role of the envelope in the survival of bacteria in infection. Medical Microbiology 3, Academic Press, London, pp 63-85.

Criado M T, Ferreirós C M, Sainz V 1985 Adherence and hydrophobicity in Neisseria meningitidis and their relationship with surface charge. Medical Microbiology and Immunology 174: 151-156.

Dahlbäck B, Hermanson M, Kjelleberg S, Norkrans B 1981 The hydrophobicity of bacteria-an important factor in their initial adhesion at the air-water interface. Archives of Microbiology 128: 267-270.

Denoya C D, Trevisan A R, Zorzopulos J 1986 Adherence of multiresistant strains of Klebsiella pneumoniae to cerebrospinal fluid shunts: correlation with plasmid content. Journal of Medical Microbiology 21 : 225-231.

Ellwood D C, Keevil C W, Marsh P D, Brown C M, Wardell J N 1982 Surface-associated growth. Philosophical Transactions of the Royal Society, London Series B 297: 517-532.

Eykyn S J 1984 Infection and intravenous catheters. Journal of Antimicrobial Chemotherapy 14: 203-205.

Feldner J. Bredt W, Kahane I 1983 Influence of cell shape and surface charge on attachment of Mycoplasma pneumoniae to glass surfaces. Journal of Bacteriology 153: 1-5.

Gilbert P, Stuart A 1977 Small-scale chemostat for the growth of mesophilic and thermophilic microorganisms. Laboratory Practice 26: 627-628.

Griffiths E 1983 Availability of iron and survival of bacteria in infection. In: Easmon C S F et al. (eds) Role of the envelope in the survival of bacteria in infection. Medical Microbiology 3, Academic Press, London, pp 153-177.

Gwynn M N, Webb L T, Rolinson G N 1981 Regrowth of larly advantageous for cells carrying a plasmid to adhere efficiently to surfaces. The virulence plasmid, col V, I-K94, enhances the attachment of $E$. coli to sand and glass in chlorinated water (Hicks and Rowbury, 1986).

We thank Drs S. H. Silverman and R. Leeming, The General Hospital, Birmingham, for supplying medical prostheses. J. A. Onaolapo acknowledges with thanks a Commonwealth Scholarship.

Pseudomonas aeruginosa and other bacteria after the bactericidal action of carbenicillin and other $\beta$-lactam antibiotics. Journal of Infectious Diseases 144: 263-269.

Harber M J, MacKenzie R, Asscher A W 1983 A rapid bioluminescence method for quantifying bacterial adhesion to polystyrene. Journal of General Microbiology 129: 621632.

Hicks S J, Rowbury R J 1986 Plasmid-associated attachment mechanisms and chlorine resistance. Abstracts of the XIV International Congress of Microbiology, Manchester, p. 230.

Hooke A M, Sordelli D O, Cerquetti M C, Vogt A J 1985 Quantitative determination of bacterial replication in vivo. Infection and Immunity 49: 424-427.

Kabir S, Ali S, Akhtar Q 1985 Ionic, hydrophobic and hemagglutinating properties of Shigella species. Journal of Infectious Diseases 151 : 194.

Kenard M A, Brown M R W, Hesslewood S R, Dillon C 1978 Influence of R-plasmid RPl on Pseudomonas aeruginosa on cell wall composition, drug resistance, and sensitivity to cold shock. Antimicrobial Agents and Chemotherapy 13: 446453.

Klemperer R M M, Ismail N T A J, Brown M R W 1980 Effect of R-plasmid RP1 and nutrient depletion on the resistance of Escherichia coli to cetrimide, chlorhexidine and phenol. Journal of Applied Bacteriology 48: 349-357.

Lachica R V, Zink D L 1984 Plasmid-associated cell surface charge and hydrophobicity of Yersinia enterocolitica. Infection and Immunity 44: 540-543.

Levin B R 1980 Conditions for the existence of R-plasmids in bacterial populations. In: Mitsuhashi $\mathrm{S}$ et al. (eds) Antibiotic resistance: transposition and other mechanisms. Springer Verlag, Berlin, p 197.

Marshall K C 1980 Bacterial adhesion in natural environments. In: Berkeley R C W et al. (eds) Microbial adhesion to surfaces. Ellis Horwood, Chichester, pp 187-196.

Maw J, Meynell G G 1968 The time division and death rates of Salmonella typhimurium in the mouse spleen determined with superinfecting phage $\mathrm{p} 22$. British Journal of Experimental Pathology 49: 597-613.

Meynell G G, Meynell E 1970 Theory and practice in experimental bacteriology, 2nd edn. The University Press, Cambridge, p 270.

Nesbitt W E, Doyle R J, Taylor K G 1982 Hydrophobic interactions and the adherence of Streptococcus sanguis to hydroxylapatite. Infection and Immunity 36: 637-644.

Onaolapo J A 1986 Effect of R-plasmid RP1 on the properties of Proteus mirabilis. PhD thesis, Aston University.

Onaolapo J A, Klemperer R M M 1986 Effect of R-plasmid RP1 on surface hydrophobicity of Proteus mirabilis. Journal of General Microbiology 132: 3303-3307.

Pedersen K 1981 Electrostatic interaction chromatography, a 
method for assaying the relative surface charges of bacteria. FEMS Microbiology Letters 12: 365-367.

Tempest D W 1978 The biochemical significance of microbial growth yields: a reassessment. Trends in Biochemical Sciences 3: $180-184$.

Tewari R, Smith D G, Rowbury R J 1985 Effect of Col V plasmids on the hydrophobicity of Escherichia coli. FEMS Microbiology Letters 29: 245-249.

Vosbeck K, Mett H 1983 Bacterial adhesion: influence of drugs. In: Easmon C S F et al. (eds) Role of the envelope in the survival of bacteria in infection. Medical Microbiology 3, Academic Press, London, pp 21-62. 